\begin{tabular}{|l|l|l||}
\hline \multicolumn{2}{|c|}{ PublisherInfo } \\
\hline \hline PublisherName & $:$ & BioMed Central \\
\hline \hline PublisherLocation & $:$ & London \\
\hline \hline PublisherImprintName & $:$ & BioMed Central \\
\hline \hline
\end{tabular}

Choosing a smell

\begin{tabular}{|l|l|l||}
\hline \multicolumn{2}{|c|}{ ArticleInfo } \\
\hline \hline ArticleID & $:$ & 3706 \\
\hline \hline ArticleDOI & $:$ & $10.1186 /$ gb-spotlight-20000622-01 \\
\hline \hline ArticleCitationID & $:$ & spotlight-20000622-01 \\
\hline \hline ArticleSequenceNumber & $:$ & 143 \\
\hline \hline ArticleCategory & $:$ & Research news \\
\hline ArticleFirstPage & $:$ & 1 \\
\hline \hline ArticleLastPage & $:$ & 2 \\
\hline \hline & $:$ & RegistrationDate : 2000-06-22 \\
ArticleHistory & $:$ & OnlineDate $: 2000-06-22$ \\
\hline \hline ArticleCopyright & $:$ & BioMed Central Ltd2000 \\
\hline \hline ArticleGrants & $:$ & \\
\hline \hline ArticleContext & $:$ & 130591111 \\
\hline \hline
\end{tabular}




\section{William Wells}

Email: wells@biotext.com

There are up to 1000 olfactory receptor (OR) genes in mice and humans, yet each olfactory neuron appears to express only a single allele of a single OR gene. In the July Nature Neuroscience, Serizawa et $a l$. succeed in detecting the expression of a mouse OR gene that they have introduced on a $200 \mathrm{~kb}$ chunk of DNA (Nature Neuroscience 2000, 3:687-693). Expression from a single OR gene is always seen, even when two identical genes labeled with different marker proteins integrate at the same genomic site, or when the integrated gene and its normal genomic counterpart are both examined. This suggests that a gene is selected for expression via a stochastic, local process, after which expression from other genes (even those with identical sequences) is prevented.

\section{References}

1. Coding of olfactory information: topography of odorant receptor expression in the catfish olfactory epithelium.

2. Nature Neuroscience, [http://www.nature.com/neuro/]

This PDF file was created after publication. 